\title{
REVIEW : POTENSI BAKTERI DARI SALURAN PENCERNAAN IKAN SIDAT (Anguilla sp.) SEBAGAI PENDEGRADASI SAMPAH PLASTIK
}

\author{
Dennisa Ameria Sendjaya ${ }^{1}$, Irna Riski Kardila ${ }^{2}$, Shafira Lestari ${ }^{3}$, Diah Kusumawaty ${ }^{4}$ \\ ${ }^{1,2,3,4}$ Program Studi Biologi, Fakultas Pendidikan Matematika dan Ilmu Pengetahuan Alam \\ Universitas Pendidikan Indonesia \\ *e-mail: dennisa.ameria@gmail.com
}

\begin{abstract}
Eel (Anguilla sp.) is found in Indonesian waters, has potential as an export commodity and is widely consumed in various countries. The microbial community found in the digestive tract of eels plays an important role. Each phase of the eel's life cycle has a different population and abundance of bacteria. Eel digestive tract bacteria have the potential to degrade plastic waste. Efforts are needed in handling increasing plastic waste. One of the efforts that can be done is biodegradation or decomposition of plastic waste by utilizing microorganisms. The purpose of this study was to determine the digestive tract bacteria of eel that have the potential as candidates for bacteria to degrade plastic waste, to determine the mechanism of degradation, and the type of plastic that is degraded. The method used is to collect secondary data through various databases. The results obtained are various types of digestive tract bacteria according to the highest abundance in each phase of the eel's life cycle that have the potential to degrade plastic waste, namely Clostridium and Aeromonas found in thephase wild eel. Shewanella and Vibrio are present in thephase fingerling wild eel. Pseudomonas and Bacillus were present in thephase eel-elver cultivated. The information obtained can be an important source of information for further research on the potential of eel digestive tract bacteria in degrading plastic waste.
\end{abstract}

Keywords: Eel, Anguilla sp., Bacteria, Digestive Tract, Plastic, Biodegradation

\begin{abstract}
ABSTRAK
Ikan sidat (Anguilla sp.) banyak ditemukan di perairan Indonesia, berpotensi sebagai komoditas ekspor dan banyak di konsumsi di berbagai negara. Komunitas mikroba yang terdapat pada saluran pencernaan ikan sidat memainkan peran penting. Setiap fase siklus hidup ikan sidat memiliki populasi dan kelimpahan bakteri yang berbeda beda. Bakteri saluran pencernaan ikan sidat memiliki potensi dalam mendegradasi sampah plastik. Diperlukan upaya dalam penanganan limbah plastik yang semakin meningkat. Salah satu upaya yang dapat dilakukan yaitu melakukan biodegradasi atau penguraian limbah plastik dengan memanfaatkan mikroorganisme. Tujuan penelitian ini adalah untuk mengetahui bakteri saluran pencernaan ikan sidat yang berpotensi sebagai kandidat bakteri pendegradasi sampah plastik, mengetahui mekanisme degradasi, dan jenis plastik yang terdegradasi. Metode yang digunakan yaitu dengan mengumpulkan data sekunder melalui berbagai database. Hasil yang diperoleh adalah berbagai jenis bakteri saluran pencernaan sesuai dengan kelimpahan tertinggi pada setiap fase siklus hidup ikan sidat yang berpotensi sebagai pendegradasi sampah plastik yaitu Clostridium dan Aeromonas terdapat pada fase eel elver wild. Shewanella dan Vibrio terdapat pada fase eel fingerling wild. Pseudomonas dan Bacillus terdapat pada fase eel elver cultivated. Informasi yang diperoleh dapat menjadi sumber informasi penting bagi penelitian selanjutnya mengenai potensi bakteri saluran pencernaan ikan sidat dalam mendegradasi sampah plastik.
\end{abstract}

Kata Kunci: Ikan sidat, Anguilla sp., Bakteri, Saluran Pencernaan, Plastik, Biodegradasi. 


\section{PENDAHULUAN}

Ikan sidat (Anguilla sp.) merupakan salah satu spesies ikan yang berpotensi sebagai komoditas ekspor dan banyak dikonsumsi di berbagai negara karena memiliki kandungan gizi yang tinggi. Ikan sidat merupakan ikan dari famili Anguillidae yang hidup di perairan Indonesia, mempunyai karakteristik habitat yang unik yaitu dapat mendiami beberapa kondisi perairan tawar, estuari, dan laut. Siklus hidup ikan sidat adalah katadromus, yaitu bermigrasi ke laut untuk memijah, larvanya bermuara ke sungai, kemudian hingga mencapai usia dewasa di perairan tawar. Saat akan bereproduksi, ikan sidat akan kembali ke laut untuk memijah (Indrawati \& Anggoro, 2016). Siklus hidup ikan sidat terdiri dari lima tahapan, yaitu leptocephalus, glass eel, elver eel, yellow eel, dan silver eel (McKinnon, 2006). Ikan sidat fase glass eel dan elver eel merupakan sidat pada stadia muda, sedangkan fase yellow eel dan silver eel merupakan stadia dewasa.

Permintaan akan komoditas ikan sidat semakin meningkat. Untuk memenuhi permintaan ekspor dan permintaan pasar yang tinggi, ikan sidat mulai dibudidayakan. Salah satu masalah yang sering dialami oleh pembudidaya sehingga menghambat produksi ikan sidat adalah berkembangnya penyakit dalam kolam pemeliharaan. Pemeliharaan benih fase glass eel hingga fase elver, hasil tangkapan dari alam mengalami masa krisis karena terjadinya perubahan kondisi lingkungan dari alam yang berpindah ke kolam budidaya. Menurut Afriyanto \& Evi (1992), kondisi lingkungan yang kurang menunjang mengakibatkan ikan mudah stres, sehingga ikan akan mengalami penurunan kemampuan dalam mempertahankan diri dari serangan penyakit bakteri oportunistik. Selain itu, penggunaan pakan yang berlebihan dan padat tebar yang tinggi menyebabkan lingkungan air pemeliharaan menjadi mediayang baik untuk pertumbuhan bakteri heterotrofik dan oportunistik (Chinabut dan Puttinaowarat, 2005).

Salah satu aspek yang berkontribusi terhadap kesehatan ikan sidat adalah keseimbangan komunitas bakteri (mikrobiota) yang terdapat pada saluran pencernaannya. Komunitas mikroba memainkan peran penting dalam perkembangan, fisiologi dan kesehatan inang (Mueller et al., 2012). Setiap fase siklus hidup ikan sidat memiliki populasi bakteri yang berbeda beda. Beberapa bakteri yang terdapat pada saluran pencernaan ikan sidat memiliki potensi, diantaranya adalah bakteri Pasteurella multocida, Staphylococcus haemolyticus, Micrococcus luteus, Citrobacter freundii, Pseudomonas mallei, Escherichia coli, Morganella morganii, Klebsiella pneumonia, dan Bacillus subtilis dapat dijadikan sebagai kandidat probiotik (Lestari \& Budiharjo, 2016). Bakteri Shewanella dan Pseudomonas mampu mendegradasi plastik (Sekiguchi et al., 2010). Bakteri, Bacillus pumilus dan Bacillus subtilis, mampu mendegradasi plastik dan menggunakan polietilen sebagai sumber karbon (Harshvardhan \& Jha, 2013).

Plastik merupakan senyawa kimia yang tersusun atas polimer rantai panjang. Penggunaan sampah plastik yang semakin meningkat dapat menyebabkan masalah seperti terjadinya pencemaran sampah plastik di laut. Sampah plastik yang ditemukan mengambang di laut menjadi kontaminan terbesar di laut. Menurut Eriksen et al. (2014), ditemukan minimal sebanyak 5,25 triliun plastik dengan berat sekitar 268.940 ton di belahan dunia 
selatan. Berdasarkan asumsi Kementerian Lingkungan Hidup (KLH), setiap hari penduduk Indonesia menghasilkan $0,8 \mathrm{~kg}$ sampah per orang atau secara total sebanyak 189 ribu ton sampah/hari. Dari jumlah tersebut, $15 \%$ berupa sampah plastik atau sejumlah 28,4 ribu ton sampah plastik/ hari. Beberapa jenis plastik yang banyak digunakan dan mencemari laut diantaranya adalah polyethylene terephthalate (PET), high-density polyethylene (HDPE), polyvinyl chloride (PVC), low-density polyethylene (LDPE), dan polystyrene (PS). Dari segi ukuran, plastik dibedakan menjadi mikroplastik $(<4,75 \mathrm{~mm})$ dan makroplastik $(>4,75 \mathrm{~mm})$ (Eriksen et al., 2014).

Beberapa upaya telah dilakukan untuk menangani sampah plastik, diantaranya dengan skrining bakteri pendegradasi plastik. LDPE banyak dimanfaatkan sebagai kantong kresek dan kantong plastik tipis digunakan sebagai media skrining bakteri. Studi tentang degradasi plastik oleh bakteri yang dilakukan oleh Sharma \& Sharma (2004) dengan menggunakan Pseudomonas terbukti dapat mendegradasi plastik low density polyethylene (LDPE) dan polyethylene (PE). Chee et al. (2010), juga mengamati beberapa spesies bakteri yang mampu mendegradasi plastik, diantaranya Bacillus dan Pseudomonas. Biodegradasi dengan menggunakan agen biologis seperti bakteri dapat menjadi salah satu yang terbaik untuk meningkatkan efisiensi degradasi (Starnecker \& Menner, 1996).

Sampai saat ini, penelitian mengenai potensi bakteri yang terdapat pada saluran pencernaan ikan sidat khususnya dalam mendegradasi sampah plastik belum pernah dilaporkan sebelumnya. Oleh karena itu, artikel ini bertujuan untuk mengetahui jenis bakteri saluran pencernaan ikan sidat dan potensinya sebagai kandidat bakteri pendegradasi sampah plastik sesuai dengan kelimpahan tertinggi pada setiap fase siklus hidup ikan sidat, dan mengetahui mekanisme degradasi serta jenis plastik yang terdegradasi oleh bakteri.

\section{METODE PENELITIAN}

Pencarian atau skrining data mengenai bakteri yang terdapat pada saluran pencernaan ikan sidat yang berpotensi sebagai pendegradasi sampah plastik dan mekanisme degradasi plastik dilakukan melalui pendekatan studi literatur dengan menggunakan data sekunder. Pada penelitian studi literatur ini penulis menggunakan berbagai sumber tertulis seperti artikel dan sumber lainnya yang terkait dengan kajian penelitian. Pencarian artikel penelitian terkait dilakukan melalui Google Scholar dengan kata kunci "Ikan sidat", "Anguilla sp.", "Bakteri saluran pencernaan", "Siklus hidup sidat", "Plastik”, "Biodegradasi", dan kata kunci lainnya. Untuk kelimpahan bakteri disetiap fase siklus hidup ikan sidat disesuaikan dengan database atau raw data yang sudah ada. Diperoleh 29 referensi yang merupakan hasil skrining. Kemudian informasi dan data diolah, lalu disusun dalam bentuk review artikel.

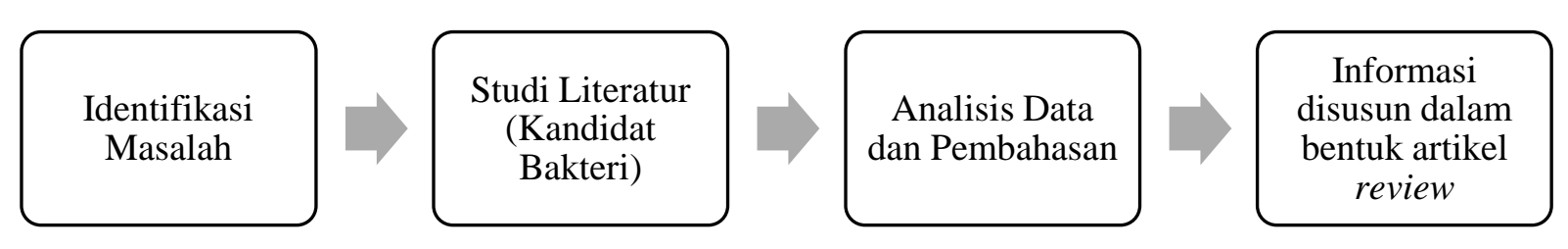

Gambar 1. Alur Penelitian 


\section{HASIL DAN PEMBAHASAN}

\section{Kelimpahan Bakteri Saluran Pencernaan Ikan Sidat yang Berpotensi Sebagai Pendegradasi Sampah Plastik}

Untuk mendapatkan bakteri pada saluran pencernaan ikan sidat yang berpotensi dalam mendegradasi sampah plastik diperlukan proses analisis metagenomik. Analisis metagenomik ini memberikan penjelasan mengenai kelompok mikrobiota atau komunitas bakteri yang terdapat pada ikan sidat serta kelimpahan dan distribusinya. Setiap fase siklus hidup ikan sidat memiliki kelimpahan bakteri yang berbeda-beda. Berdasarkan kelimpahan bakteri di setiap fasenya, terdapat beberapa jenis bakteri saluran pencernaan ikan sidat yang berpotensi sebagai kandidat bakteri pendegradasi sampah plastik, diantaranya adalah (Tabel 1.):

Tabel 1. Kelimpahan Bakteri Saluran Pencernaan Ikan Sidat dan Degradasi Polimer Sintesis Plastik

\begin{tabular}{|c|c|c|c|c|c|}
\hline \multirow{2}{*}{$\begin{array}{l}\text { Jenis Bakteri } \\
\text { Pendegradasi }\end{array}$} & \multicolumn{3}{|c|}{ Fase } & \multirow{2}{*}{$\begin{array}{c}\text { Polimer } \\
\text { Sintesis Plastik } \\
\end{array}$} & \multirow{2}{*}{ Sumber } \\
\hline & Eel Elver Wild & Eel Fingerling Wild & Eel Elver Cultivated & & \\
\hline Aeromonas & 0.172911664106 & 0.0106626929283 & 0.0290849849827 & $\begin{array}{c}\mathrm{PU} \\
\text { (polyuretane), } \\
\text { LDPE (low } \\
\text { density } \\
\text { polyethylene) }\end{array}$ & $\begin{array}{c}\text { Mzoric et al., } \\
\text { (2002); Oktaviani, } \\
\text { (2020) }\end{array}$ \\
\hline Clostridium & 0.309534655682 & 0.0893782283407 & 0.0245527614136 & $\begin{array}{c}\mathrm{PCL} \\
\text { (polycaprolacto } \\
n e \text { ) }\end{array}$ & $\begin{array}{l}\text { Ghosh et al., } \\
\text { (2013) }\end{array}$ \\
\hline Shewanella & 0.00249388111213 & 0.0208621262074 & 0.000787541403831 & $\begin{array}{c}\text { PCL } \\
\text { (polycaprolacto } \\
n e \text { ) }\end{array}$ & $\begin{array}{l}\text { Sekiguchi et al., } \\
2011\end{array}$ \\
\hline Vibrio & 0.0 & 0.00381417111267 & 0.000162140877259 & $\begin{array}{l}\text { Polystyrene } \\
\text { (PS) }\end{array}$ & $\begin{array}{c}\text { Foulon., } d k k \\
(2016)\end{array}$ \\
\hline Pseudomonas & 0.00180671263232 & 0.00187620157972 & 0.0184763390134 & $\begin{array}{c}\text { Polyethylene } \\
\text { (PE), } \\
\text { Polystyrene } \\
\text { (PS), Low- } \\
\text { Molecular- } \\
\text { Weight } \\
\text { Polyethylene } \\
\text { (LMWPE) }\end{array}$ & $\begin{array}{c}\text { Sriningsih dan } \\
\text { Shovitri, (2015); } \\
\text { Yoon, Jeon and } \\
\text { Kim., (2012) }\end{array}$ \\
\hline Bacillus & 0.0022931352641 & $1.54419883104 \mathrm{e}-05$ & 0.0032582595335 & $\begin{array}{c}\text { LDPE (low } \\
\text { density } \\
\text { polyethylene), } \\
\text { PE } \\
\text { (polyethylene) }\end{array}$ & $\begin{array}{c}\text { Fadlilah dan } \\
\text { Shobitri, (2014); } \\
\text { Harshvardhan \& } \\
\text { Jha, (2013) }\end{array}$ \\
\hline
\end{tabular}

a. Fase Eel Elver Wild

Pada fase eel elver wild, bakteri yang memiliki kelimpahan tertinggi dan berpotensi dalam mendegradasi sampah plastik adalah:

\section{Aeromonas}

Aeromonas merupakan bakteri gram negatif yang bersifat anaerob fakultatif. Aeromanas dikenal juga sebagai bakteri patogen pada ikan sidat. Bakteri ini membuat endotoksin yang dilepaskan apabila sel mati atau pecah. Endotoksin merupakan lipopolisakarida pada dinding sel bakteri. Bakteri juga menghasilkan enzim ekstraseluler yang dapat menyerang ikan sehat 
(Afrianto et al., 2015). Menurut Mzoric et al (2002), Genus Aeromonas mampu mendegradasi Poliuretan dalam jalur metabolitnya. Aeromonas dapat mendegradasi sampah plastik jenis LDPE (low density polyethylene) dengan kemampuan degradasi rata-rata sebesar $0,12 \%$ per hari (Oktaviani, 2020). Aeromonas dapat memanfaatkan partikel-partikel mikroplastik sebagai sumber karbon dan energi sehingga partikel plastik dapat terdegradasi dalam kondisi anaerob (B. yan $d k k$., 2019).

\section{Clostridium}

Clostridium merupakan
bakteri gram positif, berbentuk
batang, non-motil dan bersifat
anaerob obligat yang menghasilkan
spora. Clostridium dapat
mendegradasi sampah plastik
dibawah kondisi anaerob, jenis
sampah plastik yang didegradasi
adalah PCL (polycaprolactone).
PCL adalah polyester sintesis yang
mudah terdegradasi oleh bakteri
Clostridium botulinum (Ghosh dkk.,
2013).

\section{b. Fase Eel Fingerling Wild}

Pada fase eel fingerling wild, bakteri yang memiliki kelimpahan tertinggi dan berpotensi dalam mendegradasi sampah plastik adalah:

\section{Shewanella}

Shewanella merupakan bakteri gram negatif, berbentuk batang, motil, dan bersifat anaerob fakultatif. Shewanella merupakan bakteri pendegradasi bioplastik jenis PCL / Poly $\varepsilon$-caprolactone (Sekiguchi et al., 2011). Pada saat proses biodegradasi terjadi, bakteri ini akan membuat koloni di permukaan plastik yang akan mengeluarkan eksoenzim dan dapat memecah polimer menjadi monomer-monomer. Monomer tersebut akan digunakan menjadi sumber metabolisme untuk pertumbuhan sehingga molekul plastik menjadi terdegradasi.

\section{Vibrio}

Vibrio merupakan bakteri gram negatif, berbentuk batang pendek, memiliki flagel, dan bersifat aerob fakultatif. Bakteri ini dapat mendegradasi sampah plastik jenis PS (polystyrene), yang merupakan salah satu molekul pembentuk plastik. Menurut Foulon., dkk (2016) bakteri yang menempel pada polystyrene, salah satunya adalah Vibrio dengan menggunakan mikroplastik polystyrene sebagai substratnya dan menggunakan styrene sebagai sumber karbon.

\section{c. Fase Eel Elver Cultivated}

Pada fase eel elver cultivated, bakteri yang memiliki kelimpahan tertinggi dan berpotensi dalam mendegradasi sampah plastik adalah:

\section{Pseudomonas}

Pseudomonas merupakan bakteri gram negatif yang memiliki karakteristik sel berbentuk batang, alat gerak berupa flagela, tidak membentuk spora untuk reproduksi aseksual, dan bersifat aerob obligat tetapi dapat hidup secara anaerobik ketika berada di lingkungan dengan kandungan nitrat (Shovitri, 2015). Menurut Trevino et al. (2012), Pseudomonas dapat menghasilkan enzim serine hidrolase, esterase, dan lipase yang memiliki kemampuan mendegradasi plastik. Proses pendegradasian sampah plastik oleh enzim tersebut dapat berlangsung secara optimal jika tidak terdapat inhibitor yang mampu menghambat aktivitas enzim di lingkungan. 
Pseudomonas aktif melekat membentuk biofilm di permukaan sampah plastik selama proses pendegradasian. Plastik yang dapat didegradasi oleh bakteri ini adalah jenis PE (polyethylene) dan PS (polystyrene) selama $\geq 3$ bulan
(Sriningsih dan Shovitri, 2015). Pengamatan menggunakan SEM yang telah dilakukan oleh Yoon, Jeon and Kim (2012) mempelihatkan adanya biodegradasi LowMolecular-Weight Polyethylene (LMWPE) oleh bakteri Pseudomonas sp.
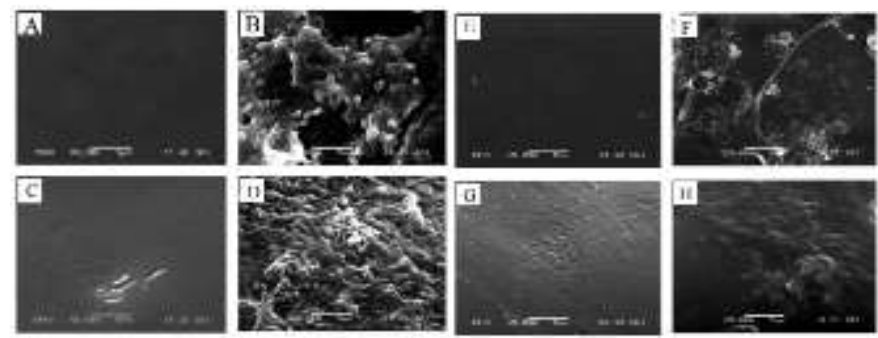

Gambar 2. Hasil SEM pada lembaran LMWPE setelah 80 hari degradasi oleh Pseudomonas sp. (A), (C), (E) dan (G); sebelum biodegradasi., (B), (D), (F) dan (H); setelah biodegradasi. (Yoon, Jeon and Kim, 2012)

\section{Bacillus}

Bacillus merupakan bakteri gram positif berbentuk batang, dapat membentuk endospora, serta bersifat anaerobik fakultatif (Fadlilah dan Shovitri, 2014). Menurut Nur (2009), degradasi sampah plastik oleh Bacillus dapat berlangsung secara aerobik dan anaerobik menggunakan enzim ekstraseluler serta intraseluler depolimerase. Sampah plastik yang dapat didegradasi oleh Bacillus adalah jenis plastik LDPE (low density polyethylene) selama 4 bulan dengan degradabilitas 2,3\% untuk plastik hitam dan 1,9\% untuk plastik putih (Fadlilah dan Shobitri, 2014).

Menurut Harshvardhan \& Jha (2013), bakteri Bacillus pumilus dan Bacillus subtilis mampu mendegradasi jenis plastik PE (polyethylene) dan menggunakannya sebagai sumber karbon. Bakteri pendegradasi plastik umumnya akan membentuk biofilm di permukaan plastik, begitu juga dengan Bacillus

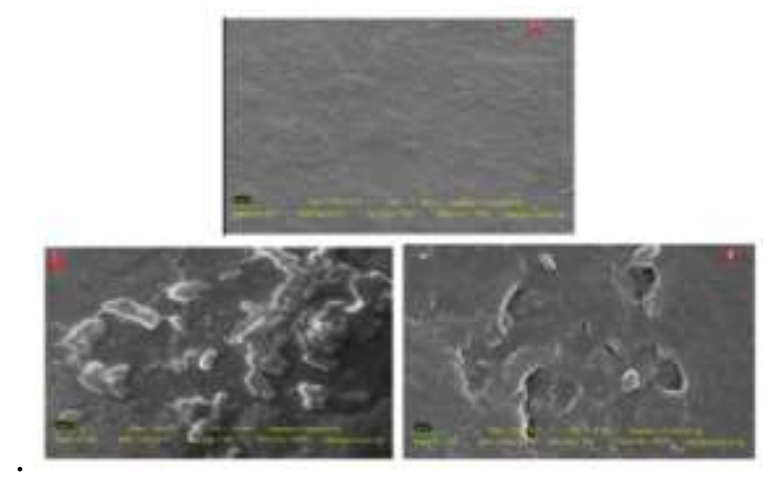

Gambar 3. Visualisasi hasil analisis SEM pada permukaan polietilen setelah 30 hari (a) tanpa inokulasi bakteri, (b) diinokulasi B. pumilus, (c) diinokulasi $B$. subtilis (Harshvardhan \& Jha, 2013) 


\section{Mekanisme Kerja Mikroorganisme Pendegradasi Sampah Plastik}

Biodegradasi merupakan suatu proses penguraian senyawa kompleks menjadi suatu senyawa yang lebih sederhana seperti air dan karbondioksida. Proses penguraian tersebut memanfaatkan aktivitas mikroorganisme sehingga terjadi perubahan integritas molekuler. Setiap mikroorganisme memiliki karakteristik yang berbeda, sehingga proses degradasi yang terjadi akan bervariasi antara satu mikroorganisme dengan mikroorganisme yang lain (Fadlilah dan Shovitri, 2014). Pada umumnya proses degradasi terjadi karena senyawa tersebut dimanfaatkan oleh mikroorganisme sebagai sumber nutrisi untuk pertumbuhannya. Kecepatan proses biodegradasi dipengaruhi oleh beberapa factor, diantaranya adalah kelembaban, jenis mikroorganisme, temperatur, $\mathrm{pH}$, jenis polimer, dan ketebalan polimer. Kondisi biodegradasi yang meliputi $\mathrm{pH}$, temperatur, nutrien, mineral, oksigen, dan kelembaban harus menyesuaikan dengan jenis mikroba yang akan digunakan sebagai biodegradator. Bahan-bahan polimer yang dilepaskan ke lingkungan akan mengalami penguraian secara fisika, kimia dan biologi atau kombinasinya yang tergantung oleh adanya kelembaban, udara, temperatur, cahaya (photo-degradation), radiasi energi tinggi (UV, $\gamma$-radiation) atau oleh hadirnya mikroorganisme (bakteri) (Sumarsono, 2011).

Terdapat empat mekanisme biodegradasi plastik di lingkungan yaitu dengan fotodegradasi atau proses penguraian dengan memanfaatkan cahaya, biodegradasi termo oksidatif atau proses degradasi dengan memanfaatkan panas, degradasi hidrolitik dan biodegradasi oleh mikroorganisme. Mikroorganisme pendegradasi limbah plastik mengubah karbon dalam rantai polimer menjadi karbon dioksida atau memasukkannya ke dalam biomolekul. Proses biodegradasi yang terjadi mengakibatkan limbah plastik menjadi rapuh dan pecah menjadi bagian yang lebih kecil, hingga rantai polimer pada limbah plastik memiliki berat molekul yang cukup rendah untuk dimetabolisme oleh mikroorganisme (Webb, 2013).

Menurut Andreas et al. (2011), tahapan utama dalam biodegradasi polimer adalah depolimerisasi atau pemecahan rantai kompleks. Polimer tergolong molekul yang kompleks, mikroorganisme tidak dapat membawa polimer melewati membrane sel sehingga mikroorganisme tersebut memerlukan strategi khusus yaitu dengan mengeksresikan enzim ekstraseluler untuk memecah polimer yang ada di luar sel. Enzim depolimerase ekstraseluler dan intraseluler berperan secara aktif dalam biodegradasi polimer. Eksoenzim dari mikroorganisme memecah polimer kompleks menjadi rantai pendek atau molekul sederhana seperti oligomer, dimer dan monomer yang larut air untuk melewati membran semi permeable sehingga mampu digunakan sebagai sumber karbon dan energi. Setelah itu, dibawa masuk ke dalam sel dan terjadi asimilasi sehingga menghasilkan produk akhir berupa $\mathrm{CO}_{2}, \mathrm{CH}_{4}, \mathrm{H}_{2} \mathrm{O}$ dan biomassa. Proses ini disebut mineralisasi (Arutchelvi, 2008) .

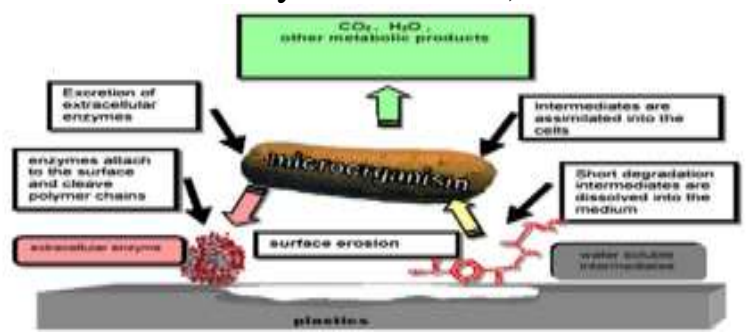

Gambar 4. Mekanisme Biodegradasi Plastik (Mueller, 2012). 


\section{KESIMPULAN}

Kelimpahan bakteri tertinggi pada saluran pencernaan ikan sidat di setiap fase siklusnya yang berpotensi sebagai pendegradasi sampah plastik, diantaranya adalah: Bakteri Clostridium dan Aeromonas terdapat pada fase eel elver wild. Lalu bakteri Shewanella dan Vibrio terdapat pada fase eel fingerling wild, sedangkan bakteri Pseudomonas dan Bacillus terdapat pada fase eel elver cultivated. Bakteri tersebut berpotensi dalam mendegradasi sampah plastik dan dapat dijadikan sebagai kandidat bakteri pendegradari sampah plastik. Tahapan utama bakteri mendegradasi sampah plastik adalah depolimerisasi dengan memecah rantai polimer yang kompleks menjadi rantai pendek sederhana. Jenis plastik yang dapat didegradadi oleh bakteri adalah: LDPE (low density polyethylene), Polyethylene (PE), Polystyrene (PS), Low-Molecular-Weight Polyethylene (LMWPE), PCL (polycaprolactone), dan PU (polyuretane).

\section{REKOMENDASI}

Perlunya penelitian lebih lanjut mengenai potensi bakteri yang terdapat pada saluran pencernaan ikan sidat sebagai pendegradasi sampah plastik serta pengaplikasiannya secara langsung agar diperoleh bakteri yang memiliki aktivitas pengurai plastik yang tinggi. Ini ditujukan agar potensi bakteri pada ikan sidat dapat dirasakan dan dimanfaatkan oleh masyarakat luas terutama dalam mengurangi sampah plastik.

\section{DAFTAR PUSTAKA}

Afrianto, E., \& Liviawaty, E. (1992). Pengawetan dan pengolahan ikan. 1989. Kanisius. Yogyakarta.
Afrianto. E., Liviawaty. E., Jamaris. dan Z., Hendi. (2015). Penyakit Ikan. Penebar Swadaya. Jakarta.

Anggarini, Debie. (2016). Aspek Klinis dan Pemeriksaan Laboratorium Clostridium perfringens Tipe A. Jurnal Kedokteran Baiturrahmah. ISSN: 2407-328X.

Anindyawati, Trisanti. (2010). Potensi Selulase Dalam Mendegradasi Lignoselulosa Limbah Pertanian Untuk Pupuk Organik. Berita Selulosa. Vol. 45 No.2

Arutchelvi, J., Sudhakar, M., Arkatkar, A., Doble, M., Bhaduri, S., \& Uppara, P. V. (2008). Biodegradation of polyethylene and polypropylene. Ind. J. Biotechno.1, 7: 9-22

Binghua Yan, Lin Luo \& Haijun Yang (2020) Isolation and characterization of Aeromonas sp. TXBc10 capable of highefficiency degradation of octylphenol polyethoxylate from tannery wastewater, Environmental Technology, 41:28, 3722-3731

Chee, J. Y., Yoga, S. S., Lau, N. S., Ling, S. C., Abed, R. M., \& Sudesh, K. (2010). Bacterially produced polyhydroxyalkanoate (PHA): converting renewable resources into bioplastics. Current research, technology and education topics in Applied Microbiology and Microbial Biotechnology, 2, 13951404.

Chinabut, S., \& Puttinaowarat, S. (2005). The choice of disease control strategies to secure international market access for aquaculture products. Developments in biologicals, 121, 255-261. 
Eriksen, M., Lebreton, L. C., Carson, H. S., Thiel, M., Moore, C. J., Borerro, J. C., ... \& Reisser, J. (2014). Plastic pollution in the world's oceans: more than 5 trillion plastic pieces weighing over 250,000 tons afloat at sea. PloS one, 9(12), e111913.

Erlambang, B. P.D., Oktaranti, R., dan Wathon S. (2019). Mikroorganisme Potensial Sebagai Agen Hayati Pendegradasi Limbah Sampah Plastik. BioTrends. Vo.10 No.2

Fadlilah FR dan Shovitri M. (2014): Potensi Isolat Bakteri Bacillus dalam Mendegradasi Plastik dengan Metode Kolom Winogradsky, Jurnal Teknik POMITS, 3, E40 - E42.

Fadlilah, Fiki Rahmah dan Maya Shovitri. (2014). Potensi Isolat Bakteri Bacillus dalam Mendegradasi Plastik dengan Metode Kolom Winogradsky. Jurnal Teknik Pomits.3(2)

Foulon, Valentin \& Le Roux, Frédérique \& Lambert, Christophe \& Huvet, Arnaud \& Soudant, Philippe \& Paul-Pont, Ika. (2016). Colonization of Polystyrene Microparticles by Vibrio crassostreae: Light and Electron Microscopic Investigation. Environmental Science \& Technology. 50. 10.1021/acs.est.6b02720.

Ghosh, S. K., Pal, S., \& Ray, S. (2013). Study of microbes having potentiality for biodegradation of plastics. Environmental Science and Pollution Research, 20(7), 4339-4355.
Harshvardhan, K., \& Jha, B. (2013). Biodegradation of low-density polyethylene by marine bacteria from pelagic waters, Arabian Sea, India. Marine Pollution Bulletin, 77(1-2), 100-106.

Indrawati, A., Anggoro, S., \& Wijaya Saputra, S. (2016). Pemetaan potensi ikan sidat (Anguilla bicolor bicolor) pada perairan sungai di Kabupaten Purworejo.

Lestari, N. W., Budiharjo, A., \& Pangastuti, A. (2016). Bakteri heterotrof aerobik asal saluran pencernaan ikan sidat (Anguilla bicolor bicolor) dan potensinya sebagai probiotik. Bioteknologi Biotechnological Studies, 13(1), 917.

McKinnon, L. J. (2006). A review of eel biology: Knowledge and Gaps. Report to EPA Victoria.

Müller, C., Townsend, K., \& Matschullat, J. (2012). Experimental degradation of polymer shopping bags (standard and degradable plastic, and biodegradable) in the gastrointestinal fluids of sea turtles. Science of the Total Environment, 416, 464-467.

Nur M. (2009) : Pengaruh Cara Pengemasan, Jenis Bahan Pengemas, dan Lama Penyimpanan terhadap Sifat Kimia, Mikrobiologi, dan Organoleptik Sate Bandeng (Chanos chanos), Nur M. (2009) : Pengaruh Cara Pengemasan, Jenis Bahan Pengemas, dan Lama Penyimpanan terhadap Sifat Kimia, Mikrobiologi, dan Organoleptik Sate Bandeng 
(Chanos chanos), Jurnal Teknologi Industri Hasil Pertanian, 14, 7.

Oktavianti, R., Rozirwan, R., \& Melki, M. (2020). Identifikasi dan uji kemampuan bakteri pendegradasi limbah mikroplastik di muara sungai musi (doctoral dissertation, sriwijaya university).

Sekiguchi, T., Sato, T., Enoki, M., Kanehiro, H., Uematsu, K., \& Kato, C. (2011). Isolation and characterization of biodegradable plastic degrading bacteria from deep-sea environments. JAMSTEC Report of Research and Development, 11, 33-41.

Sharma, A., \& Sharma, A. (2004). Degradation assessment of lowdensity polythene (LDP) and polythene (PP) by an indigenous isolate of Pseudomonas stutzeri.

Sriningsih A dan Shovitri M. (2015): Potensi Isolat Bakteri Pseudomonas sebagai Pendegradasi Plastik, Jurnal Sains dan Seni ITS, 4, E-67 - E-69

Starnecker, A., \& Menner, M. (1996). Assessment of biodegradability of plastics under simulated composting conditions in a laboratory test system. International biodeterioration \& biodegradation, 37(1-2), 85-92.

Sumarsono, T. (2011). Efektivitas Jenis dan Konsentrasi Nutrien dalam Bioremediasi Tanah Tercemar Minyak Mentah yang Diaugmentasi Dengan Konsorsium Bakteri. Skripsi. Departemen Biologi FSAINTEK Universitas Airlangga, Surabaya

Treviño AL, Gerardo GS, Raúl RH dan Cristóbal NA. (2012): Microbial Enzymes Involved in Polyurethan Biodegradation: A Review, J Polym Environ, 20, 261.

Webb, H., Arnott, J., Crawford, R., \& Ivanova, E. (2012). Plastic Degradation and Its Environmental Implications with Special Reference to (Polyethylene terephthalate). Polymers, 5(1):1-18

Yoon, M. G., Jeon, H. J., \& Kim, M. N. (2012). Biodegradation of polyethylene by a soil bacterium and AlkB cloned recombinant cell. J Bioremed Biodegrad, 3(4), 1-8. 